\title{
THE FUTURE OF THE UNITED KINGDOM
}

\author{
Sionaidh Douglas-Scott ${ }^{*}$
}

The article examines the impact of Brexit on the UK's constitutional settlement, most particularly within the field of devolution. The focus of this article is on devolution, as it argues that the voices of the three devolved nations have been too much ignored in Brexit manoeuvres, especially given that Scotland and Northern Ireland voted to remain in the EU Referendum. This article questions whether, in leaving one union (the EU), Britain may in fact destroy its own union (the UK). Does the UK have the constitutional materials to safeguard against this?

Keywords: Brexit, Constitutional Settlement, Devolution, United Kingdom, Scotland, Wales, Northern Ireland, Ireland, England

\section{TABLE OF CONTENTS}

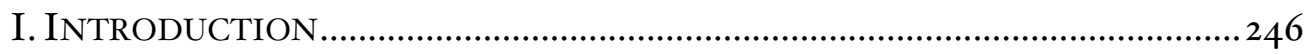

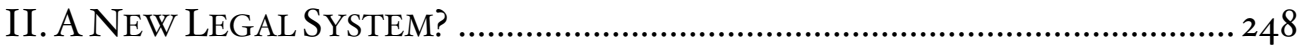

III. DEVOlution: THE TERRITORIAL CONSTITUTION IN THE BREXIT LEGISLATION AND NEGOTIATIONS ............................................................... 25I

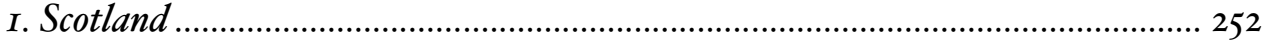

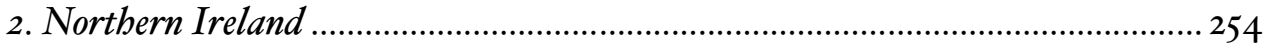

IV. THE THREAT TO DEVOLUTION …………………………………….... 256

V. BRITAIN'S AMBIVALENT TERRITORIAL CONSTITUTION ..............................260

I. 'Unitary' state? ?...…………………………………………………………… 26r

2. 'Union' state? ……………………………………………………………………...... 262

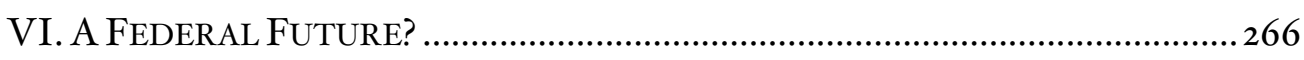

VII. CONCLUSION ………………………………………………………27

Professor Sionaidh Douglas-Scott, Anniversary Chair in Law, Queen Mary University of London; Special Advisor Scottish Parliament European/External Affairs committee Brexit inquiries 2015-2017. 


\section{INTRODUCTION}

Jacob Burckhardt, the $19^{\text {th }}$ Century Swiss historian, entitled the first section of his famous work, The Civilization of the Renaissance in Italy, 'The State as a Work of Art. ${ }^{11}$ If statecraft is a work of art, then this is a skill that has been lost or forgotten in the contemporary United Kingdom (UK). Ever since the 2016 EU Referendum, perhaps before, British governance seems to have stumbled, and to have lost its way.

Brexit is occurring at a time of constitutional instability and flux, when old certainties about the UK's Constitution have been diminishing. It is challenging a Constitution that is already 'unsettled.' ${ }^{\prime 2}$ The essence of the British Constitution has long been characterized as resting on the sovereignty of Parliament, as unwritten, flexible, uncodified in nature, with political conventions and ministerial accountability often taking the place of hard law or a Constitutional Court. ${ }^{3}$ However, this organic Constitution has in recent decades undergone a creeping reform process, provoked by certain developments which have affected sovereignty and lines of authority. These include EU membership which has challenged parliamentary supremacy; the weak entrenchment of the Human Rights Act, ${ }^{4}$ bringing increased judicial power to shape a human rights culture; and devolution in Scotland, Wales and Northern Ireland, challenging any notion of a "unitary" UK. All of this has rendered the UK and its Constitution less unitary and more heterogeneous, more willing to recognise centres of power elsewhere, without, however, bringing any coherence or consolidation of constitutional form.

As Lord Hennessey stated in the House of Lords shortly after the EU Referendum:

The referendum was like a lightening flash illuminating a political and social landscape long in the changing [...] we need to look at our internal constitutional arrangements - the relationships between the nations,

J. Burckhardt, The civilization of the Renaissance in Italy (New York Harper 1958).

Neil Walker, 'Our Constitutional Unsettlement' (2014) Public Law 529-548.

See e.g. A V Dicey, Introduction to the Study of the Law of the Constitution (Macmillan I950)

4 The Human Rights Act does not give courts the power to set aside legislation for breach of human rights. 
regions and localities of the United Kingdom. In my darker moments, I think that 23June lit a fuse beneath the Union. ${ }^{5}$

This article explores the impact of Brexit on the UK's constitutional settlement. In particular, its focus lies in the field of devolution, examined through the lens of the EU Withdrawal Act (EUWA) ${ }^{6}$ which establishes a new post-Brexit constitutional landscape. I argue that the voices of the three devolved nations have been too much ignored ${ }^{7}$ in Brexit manoeuvres, especially given that Scotland and Northern Ireland voted to remain in the EU Referendum. As Anthony Barnett has argued: 'It was England's Brexit' ${ }^{8}$ or, as Fintan O'Toole writes: 'Brexit is an essentially English phenomenon'.9 I question whether, in leaving one union - the EU - Britain may in fact destroy its own union - the UK. Does the UK have the constitutional materials to safeguard against this? And, more importantly: 'Can the $19^{\text {th }}$ century constitutional theory of the sovereign and unitary State be applied to the world of the $2 I^{\text {st }}$ century?' ${ }^{\text {Io }}$

This article is structured as follows. Part II briefly discusses the key points of the EU Withdrawal Act, which ushers in a new post-Brexit legal landscape for the UK, including for the devolved nations, while parts III and IV considers how Brexit will impact Devolution. Part V moves away from Brexit to discuss the status of the UK's existing territorial constitution and part VI

5 House of Lords, Hansard o5 July 2016, Volume 773, at column i963.

6 References to a Withdrawal Agreement in this chapter are to the Draft Agreement on the withdrawal of the United Kingdom of Great Britain and Northern Ireland from the European Union [I4 November 20I8] TF50, 55.

7 And of course, not to forget Gibraltar!

8 Barnett highlights that, while Scotland (24 per cent remain majority), Northern Ireland (I2 per cent remain majority) and London (nearly 20 per cent remain majority) voted to remain, and Wales narrowly voted to leave, what Barnett calls 'England-without-London' voted leave by an II per cent majority, in both its 'left behind' communities, and in well-off Home Counties. A Barnett, The Lure of Greatness: England's Brexit and America's Trump (Unbound Books 20I7).

$9 \quad$ F O'Toole, Heroic Failure: Brexit and the Politics of Pain (Head of Zeus Books 2018) xvi.

10 See R Schütze and S Tierney, The United Kingdom and the Federal Idea (Hart Publishing 20I8) v. 
discusses a possible federal future for the UK. Part VII concludes by reiterating the difficulties that Brexit poses for the territorial Constitution.

\section{A NEW LEGAL SYSTEM?}

A large part of this article focusses on devolution arrangements in the UK. But first, it briefly considers the basic framework for UK law and the Constitution after Brexit: the EU Withdrawal Act 2018 (EUWA), which became law on 26 June 2018. This Act will change the constitutional landscape considerably, especially with regard to the UK's four nations.

Brexit will usher in new constitutional procedures for the UK. This is partly because the EUWA introduces new categories of law. The EUWA's purpose is not - in contrast to any Withdrawal Agreement ${ }^{\mathrm{II}}$ agreed with Brussels - to decide the terms of Brexit, but to provide structures and mechanisms to prepare the UK legal system for Brexit.

The EUWA provides the apparatus for the huge revision of the UK legal system necessary as a consequence of the UK's forthcoming exit from the EU. This is 'a legal undertaking of a type and scale that is unique and unprecedented.' ${ }^{12}$ Because so much UK law has derived from the EU since I973, it is impossible for it to be replaced with new UK legislation by any "exit day". Therefore, the EUWA provides for continuity by preserving EU law as it exists immediately before Brexit, converting it into domestic law, and then, where perceived to be necessary, repealing or amending it.

A crucial point is that, if no Withdrawal Agreement is concluded, and/or if Article 50 TEU is not revoked, the EUWA will automatically apply in the event of a 'No Deal' Brexit. If, on the other hand, Parliament votes to accept a deal, the EUWA will apply after any transitional period agreed to in the Withdrawal Agreement expires. Therefore, the EUWA will, assuming Brexit takes place, form the constitutional basis of a great deal of domestic law in the future. Its impact on the UK constitution is therefore of the first importance.

II The Withdrawal Agreement (n 6).

I2 Per House of Lords Constitution Committee, European Union (Withdrawal) Bill [29January 20I8] HL 69 2017-19, 3. 
The EUWA itself is hugely complex and somewhat obscure. Its main functions, however, could be summarized as the following: first, the EUWA provides for repeal of the European Communities Act 1972 (ECA); second, it provides for legal continuity when Brexit takes place by converting EU law into national law; third, it grants ministers huge law-making powers to deal with a withdrawal from the EU; fourth, it sets out important and controversial provisions regarding devolution; and fifth, it provides for Parliament to approve any negotiated Withdrawal Agreement and framework for the future relationship with the EU. The EUWA was also notably enacted without the consent of the Scottish Parliament. It was therefore in breach of the Sewel Convention ${ }^{13}$ which states that Westminster will not normally legislate with regard to devolved matters in Scotland without the consent of the Scottish Parliament. ${ }^{14}$

The EUWA raises controversial issues, down to its very title, which was changed from the former grandiose 'Great Repeal Bill,' to the much more mundane EU Withdrawal Act. During its passage through the House of Commons in autumn 2017, Dominic Grieve described the bill as an 'astonishing monstrosity', and Chris Bryant, in the House of Commons, said:

This bill is utterly pernicious, it is dangerous, it is fundamentally un-British and I think that it has at its heart a lie. It pretends to bring back power to this country, but it actually represents the biggest peace time power grab by the executive over the legislature, by the government over parliament, in Ioo years. ${ }^{15}$

A key emphasis in the EUWA is continuity: the existing body of EU law is frozen as of exit day, and adopted as UK law. For this reason, if no other, the EUWA represents a momentous undertaking. However, continuity is

13 Further information about the Sewel Convention is available at the UK Parliament website: <https://www.parliament.uk/site-information/glossary/sewel-convention 1> accessed I7 September 2019 .

I4 And indeed, the Scottish Parliament adopted its own 'Continuity Bill', which was later subject to litigation in the UK Supreme Court - see further below.

is A Cowburn, 'Senior Tories attack "astonishing monstrosity" of Theresa May's EU Withdrawal Bill', The Independent (September I7 2017) <https://www. independent.co.uk/news/uk/politics/brexit-latest-theresa-may-withdrawal-billattacked-ken-clarke-a7934956.html> accessed I7 September 2019; Chris Bryant MP's speech is available on Hansard for II September 2017, Vol $628 \mathrm{Col} 455$. 
accomplished by means of considerable complexity. And crucially, ministers will then have considerable powers (under Sections 7 and 8 EUWA) to amend or repeal retained EU law.

Despite the general conversion of EU law into national law, Section 5(4) EUWA provides that the Charter of Fundamental Rights is not part of domestic law as from exit date. Moreover, there is to be no right of action after exit 'based on a failure to comply with any of the general principles of EU law.' ${ }^{16}$ Therefore, actions based on fundamental rights post-Brexit will be radically different from at present, and individuals will not able to pursue remedies currently available. Leading civil rights bodies have warned of a human rights deficit in the $\mathrm{UK}$ due to Brexit. ${ }^{17}$

As Vernon Bogdanor has argued, ${ }^{18}$ the EUWA (and Brexit more generally) achieves something unprecedented in the UK's constitutional history. For the withdrawal of the UK from the EU transforms a protected constitution (i.e. one that contains entrenched provisions) into an unprotected one. While the UK remains a member of the EU, because of the supremacy of EU law, neither the EU Charter, nor rights provisions in EU treaties and legislation, may be repealed by the UK Parliament, and national courts are empowered to disapply domestic legislation incompatible with those rights, as in Benkharbouche. ${ }^{19}$ Contrast this with the traditional British system of unbridled UK parliamentary sovereignty, where no entrenchment is possible and so ultimately, it is not possible to protect against abuse of legislative power. Notably, this exclusion of the Charter in the EUWA differs to the

I6 Schedule I, paragraph 3(I).

${ }_{17}$ See 'EU Withdrawal Bill will not protect UK rights: open letter' (Equality and Human Rights Commission, I4 January 20I8) <https://www.equalityhuman rights.com/en/our-work/news/eu-withdrawal-bill-will-not-protect-uk-rightsopen-letter $>$ accessed Io September 2019.

I8 Vernon Bogdanor, 'How Brexit will erase your rights' (Prospect magazine, May 2018) $<$ https:/www.prospectmagazine.co.uk/magazine/how-brexit-will-erase-yourrights $>$ accessed $1_{3}$ September 2019.

19 Benkharbouche $v$ Secretary of State for Foreign and Commonwealth Affairs [2017] UKSC 62: the Supreme Court found provisions in the State Immunity Act 1978 breached Chapters 6 and I4 ECHR and that the Charter required those provisions to be disapplied insofar as they barred employment law claims within the scope of EU law. 
position that would have been adopted under the Scottish Continuity Bill (see further below) which would have preserved the Charter in Scottish law. It also leaves open the question as to how there will exist 'equivalent rights' in Northern Ireland and Ireland after Brexit. ${ }^{\circ}{ }^{\circ}$ In many ways human rights have become devolved in the UK; for example, Scotland ${ }^{21}$ and Northern Ireland $^{22}$ have devolved human rights jurisdictions, aside from the Human Rights Act. Therefore, the imposition of a unified approach by Brexit will be keenly felt in the devolved nations.

At time of writing, much is uncertain. But Brexit has, to date, involved a forceful centralization. At present, the danger seems to be that the devolutionary aspects of Brexit have been ignored or side-lined, while negotiations between the EU and UK government proceed. Given that England lacks devolution, and the English government is merged into the general UK government, this seems to empower England over the devolved nations.

\section{DEVOlUtION: THE TERRITORIAL CONSTITUTION IN THE BREXIT LEGISLATION AND NEGOTIATIONS}

It is all too easy to forget that the $\mathrm{UK}$ is a state of four nations, yet the devolved dimensions are amongst the most problematic features of Brexit. Both the Scotland Act 2016 and the Wales Act 2017 state that devolution is a permanent part of the UK constitution, and could be abolished only by consent through popular votes in Scotland and Wales. ${ }^{23}$ Legal and constitutional protection for devolution in Northern Ireland is set out in the ${ }^{1998}$ Belfast or 'Good Friday' Agreement (B/GFA), ${ }^{24}$ which is an international treaty, implemented in the UK by the Northern Ireland Act

20 See further, Chris McCrudden, 'The Good Friday Agreement, Brexit, and Rights' (Royal Irish Academy Brexit Briefing, October 2017).

${ }^{21} \quad$ Human Rights are devolved under the Scotland Act 1998 although the Human Rights Act 1998 is reserved to the UK overall by Schedule 4 Scotland Act 1998.

22 The Northern Ireland Act 1998 includes various human rights and equality provisions, such as section 75 , which requires public bodies to have due regard to promote equality between people on the certain specific grounds.

23 Section I Scotland Act 20I6; section I Wales Act 2017.

24 Agreement Reached in the Multi-Party Negotiations, April Io 1998 ['Belfast/Good Friday Agreement']. 
I998. This provides unique constitutional arrangements for Northern Ireland - such arrangements being necessary for continued peace after the 'Troubles'. At time of writing, however, devolution in Northern Ireland has been suspended.

UK devolution since 1998 has taken place in the context of EU membership. To an extent perhaps not appreciated, the EU has provided overarching frameworks for devolved areas such as agriculture. With Brexit this will change. Once the UK leaves the EU, competences once exercised at EU level must be transferred back to the UK. But a key question is who should exercise those returned competences? Some, such as agriculture, fisheries and environment, are devolved, but others, such as trade, are reserved to the UK overall. The problem of which legal category - devolved or reserved - to return these areas of activity to has led to friction between the UK and the devolved governments.

Sections IO, II \& I2, along with Schedules $2 \& 3$ EUWA, are the main provisions dealing with devolution. They are confusing and opaque, and, while supposedly transitional, this is not at all clear from the face of the EUWA. Most controversial is Section I2 EUWA, which amends the main devolution statutes to regulate devolved competence regarding retained EU law.

Section I2 EUWA now prevents devolved authorities from amending retained EU law relating to devolved matters in ways already proscribed by regulations made by UK ministers. Before such regulations can be made, devolved legislatures must be consulted. However, ultimately they cannot block UK ministers from limiting their powers to amend retained EU law. This means the EUWA enables the UK Government unilaterally to limit devolved powers in these areas.

\section{Scotland}

The final form of Section I2 EUWA satisfied the Welsh Government, which recommended legislative consent to the Bill. However, the Scottish Parliament refused to grant its consent to the relevant sections of the EUWA, which was nonetheless adopted in Westminster, in spite of this. In addition, in March 20I8, the Scottish Parliament adopted the UK Withdrawal from the European Union (Legal Continuity) (Scotland) Act 
2018 by 95 votes to 32 . This Scottish Continuity Bill shared its structure and approach with the EUWA, seeking to complement it. However, it diverged from the EUWA in some areas. For example, it did not exclude the Charter, and allowed Scotland to keep pace with EU developments in the future. It also, in its Section $\mathbf{1 7}$, required consent of Scottish ministers should UK ministers wish to alter or repeal retained EU law within devolved areas - a provision crucial to protecting Scotland's interests, but lacking in the EUWA itself.

The legal competence of this Scottish legislation was challenged by the UK Government before the UK Supreme Court, and this lawsuit made constitutional history by being the first Act of the Scottish Parliament referred to the Supreme Court by the Attorney General under Section 33 Scotland Act I998. In a long and complex judgement, the Court found only Section 17 to be outside the Scottish Parliament's competence, due to enactments in the EUWA (subsequent to the adoption of the Scottish Continuity legislation), which prohibited its own modification. ${ }^{25}$ This effectively killed off the Continuity Bill. However, it is hard not to conclude that the Continuity Bill was largely competent when adopted by the Scottish Parliament in March 20I8. If so, surely it follows that the UK government may challenge any devolved legislation it dislikes, thus suspending its application while the matter is sub judice, and in the meantime adopting its own 'protected legislation', which by coming into force automatically trumps the devolved legislation. Does this not undermine the devolution settlement? It is likely that post-Brexit, common 'frameworks' of shared governance will need to be established over policy areas where there is an element of devolution $^{26}$ to ensure common UK approaches where necessary. Such frameworks would be a novel concept for both devolution and the UK

25 For further commentary see eg S Douglas-Scott, 'Brexit legislation in the Supreme Court: A Tale of Two Withdrawal Acts?' (Centre on Constitutional Change, 17 December 20I8) <https://www.centreonconstitutionalchange.ac.uk/opinions/ brexit-legislation-supreme-court-tale-two-withdrawal-acts $>$ accessed IO September 2019.

26 The UK White Paper on the 'Great Repeal Bill' (Legislating for the United Kingdom's withdrawal from the European Union, Cm 9446, March 2017) speaks of 'frameworks' in this context (at 8,28$)$, but it is not clear what it has in mind, and 'framework' is not used in the EUWA. 
Constitution. The problem is that UK devolution came about within the structures of the larger EU single market, so it was unnecessary to provide the detailed framework of a UK single market. How common frameworks and a UK single market may be introduced in a UK that is no longer a 'unitary' state (at least from devolution perspectives) is at present unclear.

\section{Northern Ireland}

The prospect of a post-Brexit external border between EU (Ireland) and nonEU territory (Northern Ireland) is highly problematic, not least because of memories of the role that border played in the violent recent past. The situation of Northern Ireland presents singular issues, given that the B/GFA also involves Ireland and that its terms were predicated on the joint commitment of the UK and Ireland to EU law. The EUWA therefore contains specific provisions relating to the border between Northern Ireland and Ireland and the continuation of north-south co-operation.

Section Io EUWA requires that a minister (or devolved authority) must act in accordance with the Northern Ireland Act 1998 and have regard to the 'Joint Report' ${ }^{27}$ of the EU and UK negotiators. No regulations made under the EUWA may reduce any north-south co-operation provided for in the B/GFA or create any Northern Ireland border arrangements involving physical infrastructure unless agreed between the UK and the EU.

The 'Joint Report' also contained an important guarantee that '[t]he UK commits to ensuring that no diminution of rights is caused by its departure from the EU' ${ }^{28}$ But how the EUWA's exclusion of the EU Charter sits with the seeming guarantee in the Joint Report that there is to be no diminution of rights for Northern Ireland and the B/GFA provision that human rights protected in Northern Ireland are to be equivalent to those in the Republic, and vice versa, is entirely unclear. ${ }^{29}$ If there is to be no diminution, those rights must include all rights protected by general principles of law and the

${ }_{27}$ 'Joint report from the negotiators of the EU and the UK Government on progress during phase I of negotiations under Chapter 50 TEU on the United Kingdom's orderly withdrawal from the European Union' (8 December 2017) TF50(2017)19.

28 Joint report from the negotiators of the EU and the UK (n 27) para 53, 8.

29 Chris McCrudden (n 20). 
Charter. Yet, in most respects, the EUWA does not distinguish between how rights in Northern Ireland and in the rest of the UK are treated.

It is unclear how the EUWA will interact with any Withdrawal Agreement, and future EU-UK agreements. In her Mansion House speech in March 20I7, Theresa May maintained that she had 'consistently put upholding the Belfast Agreement at the heart of the UK's approach' to Brexit. ${ }^{30}$ The Protocol on Northern Ireland to the EU/UK draft Withdrawal Agreement is intended to act as an insurance policy in case the future UK-EU relationship does not meet the commitments made in the December 2017 Joint Report. It provides a 'backstop' arrangement whereby, in the absence of a future agreed UK-EU relationship, there will be a 'common EU-UK customs territory' and certain regulatory alignments between the EU and Northern Ireland. ${ }^{3}$

However, since then the UK government has on many occasions said that the backstop arrangement is untenable as it conflicts with UK red lines on leaving the single market and customs union, as well as threatening the 'constitutional integrity of the UK'. ${ }^{32}$ However, the UK already agreed to these terms on the backstop in the Joint Report. Indeed, by backtracking on its former agreed position on the backstop, the UK government risks years of peace under the $\mathrm{B} / \mathrm{GFA}$. As such, the whole backstop problem is entirely of the UK Government's making, due to Theresa May's insistence that Brexit means the UK leaving the customs union and single market.

Furthermore, the UK has been unable to submit any workable proposals as to how a hard border could be avoided if all of the UK (including Northern Ireland) remains committed to leaving the customs union and single market. It may also be argued that the 'backstop' arrangement does not threaten the

30 Teresa May, 'PM speech on our future economic partnership with the European Union' (Gov.uk, 2 March 20I8) <https://www.gov.uk/government/speeches/pmspeech-on-our-future-economic-partnership-with-the-european-union> accessed Io September 2019.

31 See e.g. Art 8(I) Protocol which states: 'Without prejudice to the provisions of Union law referred to in Annex 5, the lawfulness of placing goods on the market in Northern Ireland shall be governed by the law of the United Kingdom as well as, as regards goods imported from the Union, by Chapters 34 and 36 TFEU.'

32 See e.g. 'Brexit deal will not jeopardise UK integrity, vows Raab', BBC News (2 November 2018) <https://www.bbc.com/news/uk-northern-ireland-46065909> accessed 17 September 20I9. 
constitutional integrity of the $\mathrm{UK}$, as there is already considerable differentiation within UK legal and constitutional arrangements. This point will be discussed further below.

\section{The THREAT TO DEVOLUTION}

EU membership provided support and reinforcement for UK devolution. A UK single market was supplanted by an EU single market, enabling a different sort of devolution settlement, with less direct control from London. Membership of the EU also sheltered devolved nations from a unitary UK approach by, for example, distributing EU funding on a more favourable basis to some areas of the UK than others (as with agriculture). This approach is unlikely to continue after Brexit, and in its place, a unified UK approach is more likely, however detrimental to devolved interests. The EU setting also diminished the significance of the border across Ireland, and reconciliation between the UK and Ireland took place within the framework of common EU membership.

The UK lacks a codified Constitution, but devolution statutes have functioned as mini-constitutions, ${ }^{33}$ directly binding devolved legislatures to EU law and the ECHR. There has been a visible trend over the past 20 years of divergence and differentiation regarding UK constitutional arrangements, as well as the growth of more progressive constitutional forms in devolved nations. In particular, the Scotland Act 2016 and Wales Act 2017 brought extensive new powers. Neil MacCormick has publicized the concept of 'post sovereignty, ${ }^{\prime 34}$ a concept embraced by those who view the EU as providing for authority and competences to be divided, pooled and shared both above and below state level.

33 They set out the principal governance arrangements for these nations, as well as legal standards, such as EU law, and the European Convention on Human Rights, that must be complied with.

34 N MacCormick, 'On Sovereignty and Post-Sovereignty' in N MacCormick 2uestioning Sovereignty: Law, State, and Nation in the European Commonwealth (OUP 1999). 
Nonetheless, there exist deficiencies in the devolution structures and processes. To be sure, the UK acknowledges its 'nations'35 of England, Scotland, Wales and Northern Ireland, but their autonomy remains limited. Most notably, UK devolution appears to leave Westminster parliamentary sovereignty unaffected. Sovereignty has not actually been legally divided as in federal systems, and the weak Sewel Convention (even in its statutory form ${ }^{36}$ ), requiring that Parliament should not normally legislate with regard to devolved matters without devolved consent, governs instead. The adoption of the EUWA without the consent of the Scottish Parliament affirms Parliamentary sovereignty, and is significant and controversial. ${ }^{37}$ While such consent is not legally necessary, it is required as a matter of constitutional convention - a convention which Westminster itself recently legislatively endorsed. The UK Supreme Court held in Miller that the Sewel Convention is not legally enforceable, it is only a convention. ${ }^{38}$ Westminster is supreme and may legislate on any matter, including devolved issues. However, the EUWA's adoption without Scottish consent illustrates how mechanisms based on self-restraint and mutual trust may break down, and have sober implications for the stability of the UK.

Furthermore, even prior to the EU referendum, devolution was characterised by weak institutional relationships between the UK central government and the devolved institutions. For example, the Joint Ministerial Committee (JMC) functioned informally, its structures set out in MOUs, with no legal powers, and even failed to operate at all from 2002-2007. ${ }^{39}$ Brexit has further revealed the lack of shared approaches, and lack of trust, between devolved

35 Notably, in 20I0, Spain's Constitutional Court stated that 'The interpretation of the references to "Catalonia as a nation" and to "the national reality of Catalonia" in the preamble of the Statute of Autonomy of Catalonia have no legal effect."

36 See Scotland Act 1998, s28(8), as inserted by Scotland Act 2016, s2.

37 Notably, the Scottish Government also declined to recommend the Scottish Parliament consent to other Brexit Bills, namely the Healthcare and Agriculture Bills, due to the UK Government's proceeding in spite of refusal of consent to the EUWA, which the Scottish Government views as effectively suspending the Sewel Convention.

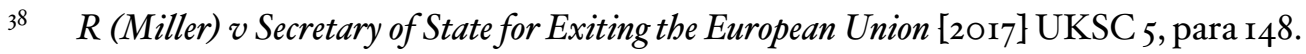

39 See House of Lords Constitutional Committee: 'Inter-governmental relations in the UK' (II ${ }^{\text {th }}$ Report, session 20I4-15, HL Paper I46) which found the JMC to be working unsatisfactorily. 
and central governments. Matters were not improved when the EUWA returned from the Lords to the Commons in June 20I8, and no Scottish MP was given time to speak on this topic, and all SNP members walked out of the Chamber. This was dismissed by some as a 'stunt', ${ }^{40}$ but is a serious matter, given that the Scottish Parliament had already refused legislative consent to the EUWA and adopted its own 'Continuity Bill' rivalling the EUWA.

The exclusion of devolved government participation in the Brexit negotiations is significant. Although the Scottish Government argued for a differentiated Brexit solution for Scotland, to reflect the different referendum vote, in its paper, 'Scotland's Place in Europe', this was rejected by the UK Government. ${ }^{4 \mathrm{I}}$ This rejection left no space for Scotland to protect its interests, in a situation where the UK government has embraced a unitary, top-down approach, excluding devolved governments from negotiations. ${ }^{42}$

Equally relevant is the current absence of devolved government in Northern Ireland. This effectively excludes a Northern Irish voice in Withdrawal negotiations, with the exception of the currently powerful voice of Democratic Unionist Party (DUP) MPs, who are supporting, via a confidence and supply agreement, the UK government at Westminster. How does this square with the requirement for UK government neutrality in the $\mathrm{B} / \mathrm{GFA}$ ? The B/GFA sets out complex constitutional arrangements to achieve a peace settlement in Northern Ireland. One such provision in effect

40 Pippa Crerar, Peter Walker and Libby Brooks, 'SNP MPs walk out of Commons in protest over Brexit debate', The Guardian (I4 June 2018) $<$ https://www.theguardian.com/politics/20r8/jun/ı3/snp-mps-walk-out-ofcommons-in-protest-over-brexit-debate $>$ accessed I7 September 2019.

${ }_{41}^{4}$ 'Scotland's Place in Europe' (The Scottish Government 2016) $<$ http://www.gov.scot/Resource/005I/005I2073.pdf> accessed Io September 2019.

42 See further on this S Douglas-Scott 'Brexit and the Scottish Question' in F Fabbrini (ed) The Law and Politics of Brexit (OUP 2017). On 5 March 2019, Nicola Sturgeon stated in the Scottish Parliament (of Theresa May): 'Perhaps her one and only note of consistency in all of this, over the past two-and-a-half years, has been her contempt for Scotland and the position of the Scottish Parliament.' See further: Andrew Learmonth, 'Historic day as Scottish and Welsh parliaments reject May's Brexit deal' (The National, 5th March 2019) <https://www.thenational. scot/news/17478439.historic-day-as-scottish-and-welsh-parliaments-reject-maysbrexit-deal/?ref=mr\&lp=8> accessed Io September 20 I9 . 
sets out a legal means for Northern Ireland to secede ${ }^{43}$ from the rest of the UK (the only UK nation to have this set out in law). ${ }^{44}$ This ensures Northern Ireland's consent to remaining in the UK. Opponents of the 'backstop' express the view that it threatens the 'constitutional integrity' of the UK. ${ }^{45}$ However, leaving open the possibility of 'No Deal' and a return to a physical border across Ireland, this may lead to the re-emergence of a mainstream Irish unity debate in Northern Ireland ${ }^{46}$ and a majority vote in Northern Ireland for unity with Ireland. The government's handling of Brexit is a departure from the careful constitutional approach of the B/GFA and could constitute a greater threat to the constitutional integrity of the UK.

Finally, it must be noted that England was omitted from the devolution legislation, and unlike the other three nations, lacks its own dedicated Parliament. Although EVEL ('English votes for English laws') provides some mitigation - albeit mitigation of extreme complexity - there is no obvious solution to the asymmetric patterns of devolution in the UK, an element which has caused ill-feeling and may have contributed to the rise of English nationalism. Notably, both EVEL and the EU in-out referendum were Conservative election manifesto pledges in 2015 - both unsatisfactory

43 Under Constitutional Issues, s I(ii) of the B/GFA states that 'it is for the people of the island of Ireland alone, by agreement between the two parts respectively and without external impediment, to exercise their right to self-determination on the basis of consent, freely and concurrently given, North and South, to bring about a united Ireland, if that is their wish, accepting that this right must be achieved and exercised with and subject to the agreement and consent of a majority of people of Northern Ireland'.

44 Unlike Scotland, which in the context of the 2014 independence referendum, was specifically authorized by UK ministers under a 's.3o order' (of the Scotland Act 1998) to conduct the referendum.

45 See e.g. 'Brexit deal will not jeopardise UK integrity, vows Raab', $B B C$ Newes (2 November 2018) <https://www.bbc.com/news/uk-northern-ireland-46065909> accessed i7 September 2019.

46 See further for research indicating this: A Kramer, Brexit, Northern Ireland, and Devolution (Centre on Constitutional Change, I October 20I8) $<$ https://www.centreonconstitutionalchange.ac.uk/opinions/brexit-northernireland-and-devolution $>$ accessed Io September 2019. 
remedies for rising English nationalism, as they have divided the UK, and failed to stem the rise of English nationalism. ${ }^{47}$

Therefore, Brexit places the UK's fragile territorial constitution in sharp relief. Brexit was supposed to be about 'taking back control' and regaining sovereignty. Yet Brexit imperils the very national sovereignty and selfdetermination that its advocates believe it will bring. It risks shattering the delicate balance and stability of the UK by threatening the peace settlement in Northern Ireland and raising the possibility of another independence referendum in Scotland. Indeed, on 28 May 20I9, the Scottish Government introduced a Referendums (Scotland) Bill ${ }^{8}$ to set the rules for any referendum within the competence of the Scottish Parliament. Unlike the $20 \mathrm{I} 4$ independence referendum, this Bill has been designed to avoid the need for UK approval by means of a 's.30 order' granting the Scottish Parliament the competence to hold an independence referendum.

The process has also clearly illustrated the lack of possibilities for UK substate entities to input or influence vital decisions made on Brexit, as well as how the UK government has insisted on centralizing and proclaiming its domination of the whole withdrawal process. We might conclude here that, within the existing Westminster parliamentary framework, the (minority) UK government has been able to appropriate a great deal of executive power to control the Brexit process for its own purposes. Yet Brexit has consequences of huge constitutional importance, not least for the devolution system, and the capacity to destabilise the UK's own constitutional foundations.

\section{BRITAIN'S AMBIVALENT TERRITORIAL CONSTITUTION}

Is it possible to preserve the UK in the face of Brexit? It seems unlikely that structures provided by the 1688 constitutional settlement, which gave rise to parliamentary supremacy, can resolve the revolution unleashed by Brexit, partly because the devolved nations have now experienced constitutional

47 See further on this, 'Will England ever get its own Parliament?', BBC Neres (7 June 20I8) <https://www.bbc.com/news/uk-politics-44208859> accessed I7 September 2019 .

48 The Bill may be found here: <https://www.parliament.scot/parliamentary business/Bills/III844.aspx> accessed Io September 20I9. 
transformation, and are more open to modified and circumscribed sovereignty than England. Part of the problem is the inconclusive nature of Britain's current constitutional arrangements. Britain is a devolved polity but what does this mean? And how does devolution compare to federalism, or to a 'unitary' or 'union' state? Pufendorf, in the $\mathrm{I} 7^{\text {th }}$ century, described the Holy Roman Empire as an irregular body like some misshapen monster ${ }^{49}$ and the UK today might appear irregular and misshapen, if not monster-like.

\section{I. 'Unitary' state?}

For example, parliamentary supremacy notwithstanding, it would not be correct to describe Britain as a 'unitary' state. The term 'unitary state' suggests a constitutional order with a single, ultimate legal competence, subscribing to a fundamental 'rule of recognition,'50 placing a central authority or Institution, for example the Queen in Parliament, in a position of indisputable authority. While the UK is often characterized as a 'unitary' state, such a classification fails to convey the diversity within it. ${ }^{51}$

Devolution is not symmetric. There exist different constitutional settlements in each of the devolved nations, as well as in England, which lacks devolution (other than at local government level). The Scottish and Welsh Parliaments and governments are stated in UK legislation to be permanent, ${ }^{52}$ and Scotland is now one of the most devolved territories anywhere in Europe, 53 including, since the Scotland Act 20I6, its shared taxation powers. (However, Section 28 Scotland Act 1998 explicitly sets out the ultimate sovereignty of the Westminster Parliament over Scotland, and Scotland and Northern Ireland were not able to protect overall votes for 'Remain' in the

49 S Pufendorf, Of the law of nature and nations, in B Kennet (trans) (London 1717) vi-9, 152.

50 See HLA Hart, The Concept of Law (Oxford Clarendon Press 196r).

${ }^{5} \quad$ See further: R Schütze and S Tierney, The United Kingdom and the Federal Idea (Hart Publishing 20I8).

52 E.g. Scotland Act 2016.

53 Partly as a result of attempts in the 2016 Scotland Act to follow up on the 'Vow' of Unionist parties in the run up to the 2014 independence referendum and proposals of the Smith Commission thereafter. 
EU Referendum). ${ }^{54}$ The B/GFA set up a power sharing assembly in Northern Ireland, but also a North-South council (Eire-Northern Ireland) and EastWest (Northern Ireland-Westminster) institutions. There also exists some entrenchment in the Northern Ireland Act 1998 due to its provisions on a referendum on continued UK membership. There never has been a UK-wide system for allocating resources according to need. Instead, each of the devolved nations has its own funding settlement negotiated bilaterally with the centre.

In these ways, the ultimate control of the centre seems to be undermined and there exist competing constitutional narratives in the periphery of the UK to the concept of a unitary UK state. Yet the working of these arrangements has been challenged by Brexit.

\section{2. 'Union' state?}

It has been suggested that Britain should be classified as a 'union' rather than a unitary state. The concept of union is much used by scholars in political and constitutional studies to denote the consolidation of distinct, extant units into one, single entity, and Rokkan and Urwin ${ }^{55}$ have used the term to describe a polity distinct both from the unitary and the federal state.

Vernon Bogdanor characterized devolution as 'the start of a new song [...] in which the United Kingdom is becoming a union of nations, each with its own identity and institutions. ${ }^{156}$ The Union of Scotland and England was the founding act of the UK in 1707 . Before then, there was no British state. This

54 In 2014 David Cameron, then Prime Minister, stated in response to an SNP proposal that the UK should only leave the EU if a majority in each of the UK's four constituent parts had voted to do so: 'We are one United Kingdom. There will be one in/out referendum (for the EU) and that will be decided on a majority of those who vote.' See 'Cameron rejects giving Scotland veto in EU referendum' Reuters, (29 October 2014) <https://uk.reuters.com/article/uk-britain-eu-scotland/ cameron-rejects-giving-scotland-veto-in-eu-referendumidUKKBNoIIIEV20I4IO29> accessed I7 September 2019.

55 S Rokkan and D Urwin, Economy, Territory, Identity: Politics of West European Territories (Sage Publications 1983).

${ }_{56}$ V Bogdanor, Devolution in the UK (OUP 1998) 287. 
was labelled an 'incorporating'57 union, yet Scotland always maintained a distinctive profile secured in the Treaty and Articles of Union. Scotland's Parliament was dissolved, but Scotland maintained its judiciary and legal system, most of its local government, its universities and Presbyterian church - so in many ways, this was a partial union. ${ }^{58}$ In I80I, the Union of Great Britain and Ireland abolished the Dublin Parliament and provided for direct rule from Westminster. But it also set out protections for Ireland, although more limited than those for Scotland. ${ }^{59}$ This illustrates that, even prior to devolution, the UK was asymmetric. However, what is perhaps curious, is that these Acts of Union, these 'constituting treaties', came to be seen as ordinary legislation under the prevalent paradigm of a Diceyan parliamentary sovereignty. ${ }^{60}$ So guarantees given to the Scots in the Act of Union appeared worthless. However, as Lord Cooper stated in the Scottish Court of Session: 'The principle of the unlimited sovereignty of parliament is a distinctively English principle which has no counterpart in Scottish constitutional law'. ${ }^{6}$

Nevertheless, by the later $19^{\text {th }}$ century, pressure for increasing differentiation was mounting. In Ireland, 'home rule,' was demanded, namely, repatriation of most competences and an Irish Parliament overseeing all domestic matters. Westminster passed the 1914 Government of Ireland Act, but this was not implemented due to the First World War, and in I9I6 the Easter Rising took place, followed by the Irish war of independence. In 1922 Ireland acquired Dominion status - a constitutional compromise between British authorities and Irish nationalist rebels, who demanded a complete break from the UK. In 1937, the 1922 Dominion Constitution was replaced by Ireland's existing Constitution. Prior to then, however, Ireland was

57 Interestingly, the initial requirement of the Scottish commissioners was for the formation of a 'federal union', by which they meant a loose association retaining separate parliaments. See e.g. W Ferguson, 'The Making of the Treaty of Union of I707' (1964) 43 The Scottish Historical Review 89, I03.

$5^{8}$ See egJ D Ford, 'The Legal Provisions in the Acts of Union' (2007) 66 Cambridge Law Journal ro6.

59 See further on this, A Jackson, The two Unions: Ireland, Scotland, and the survival of the United Kingdom, 1707-2007 (OUP 2012).

60 Dicey stated that no 'limitations imposed by law on the absolute authority of Parliament has any real existence.' A V Dicey, Introduction to the Study of the Law of the Constitution, (Macmillan I950 ed) 68-70.

6r MacCormick v Lord Advocate 1953 SC 396, 1953 SLT 255. 
partitioned so Northern Ireland remained part of the UK. ${ }^{62}$ The current constitutional settlement in Northern Ireland, set up as part of the peace process, suggests that pragmatic, variegated constitutional solutions are needed, rather than absolutist and uncompromising Acts of Union. ${ }^{63}$

Returning to Scotland, from the I990s, a different type of Scottish nationalism surfaced, along with devolution, which enabled more progressive constitutional forms, for example different voting systems for the Scottish Parliament making it more representative of the electorate. However, it also posed a challenge to unitary parliamentary sovereignty. The Scottish Parliament and Government have been portrayed as representing the 'sovereign' right of the Scottish people. ${ }^{64}$ The discord between these two approaches is visible with Brexit, where Scotland voted to remain in the EU - a discord which may well lead to a second Scottish independence referendum. In March 2017, Nicola Sturgeon requested the UK Government to adopt a section 30 order for a second Scottish Independence Referendum before the spring of 2019. This request was rejected by Theresa May, but the issue has not gone away, and in May 2019, the Scottish Government introduced a Referendums (Scotland) Bill, enabling the Scottish Government to launch an independence referendum, without the need for UK government approval by means of a 's3o order' under 530 Scotland Act $1998 .{ }^{65}$ The suggestion is that such a referendum might be held later in $202 \mathrm{O}$.

Surprisingly, regardless of the challenge of the Scottish independence referendum in 20I4, there has been little debate about what the 'Union' or 'UK' is or should be, despite further devolution legislation (Scotland Act 2016 and Wales Act 20I7) having since been adopted. The historical nature and

62 See further on partition TE Hachey, 'One people or two? The origins of partition and the prospects for unification in Ireland', (1973) Journal of International Affairs 232.

63 See further J Tonge, 'The impact of withdrawal from the European Union upon Northern Ireland' (2016) Political Quarterly I.

${ }^{64}$ See further, on popular sovereignty in Scotland, N MacCormick, 'Sovereignty: Myth and Reality' (1995) Scottish Affairs I.

65 See eg Jess Sargeant, 'A second referendum on Scottish independence' (Institute for Government, 30 May 2019) <https:/www.instituteforgovernment.org.uk/ explainers/second-referendum-scottish-independence> accessed I3 September 2019. 
meaning of the union, and of Britain, has been largely ignored, and there exists no written Constitution nor legal tradition to explain the constitutional identity of the United Kingdom.

The historian, Linda Colley ${ }^{66}$ uses the term 'composite state' as a concept essential to understanding the UK Union. ${ }^{67} \mathrm{~A}$ key feature is that of consent, whereby the several peoples of a composite state may renegotiate their relationships with each other. Colley's point is that the existence of a composite state depends upon competent management, as well as a vision to hold it together. At present, the UK appears to have neither. Without shared conceptions of a British nation, or shared constitutional doctrines, the rationale for keeping the Union is largely negative, its continued existence dependent on primarily pragmatic reasons, such as economic and social benefits. Yet Brexit threatens these very benefits.

In her Mansion House speech in March 2017, Theresa May stated that she 'would not allow anything that would damage the integrity of our precious Union. ${ }^{68}$ Yet there is no longstanding, unchanging identity to this union. From 1707 , it has been characterized by a dynamic, fluctuating character, which has enabled it to accommodate serious challenges such as the loss of Ireland and end of the Empire. At the same time, there has also always been a risk that the Union may disintegrate in the future. As a result of devolution, the UK has been 'hollowed out', yet, as Tierney writes, 'this has been without any sense of coherent planning, ${ }^{169}$ and the purpose of devolution has never clearly been articulated.

66 L Colley, Acts of Union and Disunion (Profile Books 2014).

${ }_{67}$ Historians such as David Armitage explain how composite statehood was a feature of early modernity, D Armitage, Ideological Origins of the British Empire (CUP 2000); see also L Benton, $A$ Search for Sovereignty; Law and Geography in European Empires I400-I900 (CUP 2010).

68 T May, 'Speech on our future economic partnership with the European Union', speech at Mansion House (Gov.uk, 2 March 2018) <www.gov.uk/government/ speeches/pm-speech-on-our-future-economic-partnership-with-the-europeanunion $>$ accessed ${ }_{7} 7$ September 2019.

69 S Tierney, 'Drifting towards Federalism?' in Schutze and S Tierney (eds) The United Kingdom and the federal idea (Hart 2018) 102. 


\section{A FEDERAL FUTURE?}

Could a federal UK and/or a written constitution emerge out of the constitutional morass of Brexit? Some commentators have advocated federalism ${ }^{70}$ as a solution for the UK. Part of the purpose of federalism is to foster diversity in union, which fits well with the UK's existing diverse form. The UK is already a devolved state, and the rise of 'post sovereignty' arguments, referenced earlier, raise issues about the relationship of Britain's component parts to the centre, each other, and to the EU, questions clearly part of the federalist mindset.

Undoubtedly, Britain has demonstrated some federalist tendencies. The I707 Treaty of Union with Scotland demonstrated such tendencies, which resurfaced in the I860s with the Irish movement for Home Rule, and a bit later with the Imperial Federation movement. ${ }^{71}$ Winston Churchill even considered a federal union with France in $1940 .{ }^{72}$ Bogdanor described the UK as 'quasi-federal.'73 Since the I990s these federal tendencies have gained momentum. The 1998 Human Rights Act could be compared with Bills of Rights operating in federal constitutions, and the UK Supreme Court, brought into existence in 2009 , has increasingly taken on characteristics of a

70 See further e.g. G Brown, 'Brexit is an opportunity to make a federal United Kingdom' Financial Times (March 28 2017) <https://www.ft.com/content/c4658ba8I30a-IIe7-boci-37e4I7ee6c76> accessed I3 September 20I9; A Blick, 'Devolution, federalism and the UK Constitution: Lessons and implications of the Brexit process' The Federal Trust (June 2018) < https://fedtrust.co.uk/the-united-kingdoma-federal-perspective/the-changing-uk-constitution/devolution-federalism-andthe-uk-constitution/> accessed I3 September 2019; 'The United Kingdom: Federalism or Bust?' collected essays of the Federal Trust (June 2015) $<$ https://fedtrust.co.uk/wp-content/uploads/2015/o6/Federalism_or_Bust.pdf/> accessed I3 September 2019; S Douglas-Scott 'Britain and the European Union: Federalism and Differentiation' in Schutze and S Tierney (eds) The United Kingdom and the federal idea (Hart 2018).

${ }_{71} \quad$ See e.g. W Roy Smith, 'British Imperial Federation' (I92I) 36 Political Science Quarterly 274-297.

${ }_{72}$ See further, M Burgess, The British Tradition of Federalism (Leicester University Press 1995); John Kendle, Federal Britain (Routledge 1997).

73 Bogdanor, Devolution in the UK (OUP 200I). 
Constitutional Court one might find in a federal jurisdiction, ${ }^{74}$ with an increased caseload involving human rights or constitutional issues. As stated, the devolution statutes have the capacity to function as 'mini constitutions,' for example, setting out a division of competences between reserved and devolved matters.

However, the UK is not a federal state. Although there was a brief period of enthusiasm before the First World War for 'home rule all round', ${ }^{75}$ nothing came of this and federalism has never operated within the UK. Somewhat ironically, Britain helped generate federations elsewhere - in Canada, Australia, South Africa and India - mostly devised to provide structures in which diverse ethnic groups and cultures could get along, side by side. Yet Britain's own current federal traits should not be overemphasised. Constitutional supremacy in the UK resides in Parliament, not in a codified constitutional text interpreted by courts. Also, the House of Lords, Britain's upper parliamentary chamber, does not function on a territorial basis, as a states' chamber, as it might do in a federal system. A major reason why the UK has not developed as a federal state lies in a fixation on parliamentary sovereignty, which has put a stop to exploration of other constitutional forms. Indeed, in some quarters there might seem to be an antipathy to federalism, characterized as 'Neurosis' by Marquand. ${ }^{76}$

However, the concept of federalism is itself open to contestation. As Halberstam suggested, federalism can be a charged and confusing word. ${ }^{77}$ Some view it as enabling decentralization, whereas, for others, on the contrary, it indicates a strong central government. In his notable work, Wheare defined federalism as 'the method of dividing powers so that the general and regional governments are each, within a sphere, coordinate and independent. ${ }^{17}$ Yet this definition seems to ignore cooperative elements of federalism by which various levels of governance are not necessarily

74 I.e. determining cases, often involving matters of competence, coming from only one of the UK's national jurisdictions.

75 In I886, the Liberal Unionist Joseph Chamberlain called for 'home rule all round'.

76 D Marquand, 'Federalism and the British: Anatomy of a Neurosis' (2006) 77 The Political Quarterly 150

77 D Halberstam, 'Federalism: Theory, Policy, Law', in M Rosenfeld and A Sajó (eds) The Oxford Handbook of Comparative Constitutional Law (OUP 2012) 578.

$7^{8}$ KC Wheare, Federal Government (OUP I946) II. 
autonomous but compete and intermingle. ${ }^{79}$ Alternatively, Elazar's account of federalism as a combination of 'self-rule plus shared rule' extended federalism's scope so it is perhaps better seen as 'a family of ideas and practices that developed and diverged across history and in multiple contexts. ${ }^{180}$

Trading arrangements post-Brexit raise federal questions. Federal and other non-unitary states have made provision to ensure policy harmonization. For example, the US federal Constitution contains the Commerce Clause, which states that the US Congress shall have power '[t]o regulate Commerce with foreign Nations, and among the several States, and with the Indian Tribes. ${ }^{18}$ However, post-Brexit, it is difficult to determine what the UK Government has in mind - whether it plans some new intra-governmental machinery, or legislation for UK-wide free movement principles which courts could enforce $^{82}$

A federal future for Britain might be a 'strategic compromise', ${ }^{8}$ averting the approach of first-past-the-post politics. This 'winner-takes-all' approach had the result that, even with a close referendum result, and two nations voting to remain, the UK government focussed on those voting leave, affording little accommodation to those wishing to remain in the EU. But could proponents of federalism ever get beyond the brick wall of parliamentary sovereignty?

Federalism has some political support in the UK. In 20I6, the Constitution Reform Group, ${ }^{84}$ a group of those desiring to retain the UK Union, argued

79 See e.g. Robert Schütze, From Dual to Cooperative Federalism: The Changing Structure of European Law (OUP 2009).

8o Per D Armitage, 'We have always been federal' in Schutze and Tierney in Schutze and S Tierney (eds) The United Kingdom and the federal idea (Hart 2018) 278.

${ }_{81} \quad$ United States Constitution (Chapter I, Section 8, Clause 3).

82 See further, C Barnard, 'Brexit and the EU Internal Market' in F Fabbrini (ed) The Law and Politics of Brexit (OUP 2017).

$8_{3}$ See further Seema Syeda, 'Brexit, federalism and Scottish independence' (UCL Constitutional Unit, February 23, 20I7) <https://constitution-unit.com/2OI7/ 02/23/brexit-federalism-and-scottish-independence/> accessed Io September 2019.

${ }^{84}$ Further information is available on the group's website at $<$ http://www.constitutionreformgroup.co.uk>. 
for radical constitutional change. ${ }^{85}$ They argued that devolution should be 'turned upside down' to create a federal Britain, advocating replacing the existing union with fully devolved government in each part of the UK, each with complete sovereignty over its own affairs. The group proposed that shared UK functions would include the monarchy as head of state, foreign affairs, defence, national security, immigration, international treaties, human rights, the supreme court, a single currency, a central bank function, financial services regulation, income and corporation tax powers, and the civil service. Other functions would be controlled by the nations, similar to the 'devo-max' proposal often promoted in Scotland. ${ }^{86}$ The Group's proposals were drafted into a (Private Member's) Act of Union Bill, ${ }^{87}$ introduced in the House of Lords in October 2018 by Lord Lisvane and currently awaiting a second reading. ${ }^{88}$

The Constitution Reform Group is only one of several proposals ${ }^{89}$ for a more federal UK. A further example is that of Welsh former First Minister Carwyn Jones, who proposed that a UK Council of Ministers would take over from

85 Martin Kettle, 'Brexit vote paves way for federal union to save UK, says all-party group' The Guardian (Io July 2016) <https://www.theguardian.com/politics/ 20I6/jul/ro/brexit-vote-paves-way-for-federal-union-says-all-party-group/> accessed ro September 2019.

86 'Devo-max' would give Holyrood the power over most reserved matters, except defence and foreign affairs. It was discussed but not offered on the ballot in the 2014 Scottish Independence Referendum.

${ }_{87}$ Available at <http://www.constitutionreformgroup.co.uk/wp-content/uploads/ 2018/Io/CRG-Act-of-Union-Bill.pdf> accessed 9 September 2019; discussion paper and explanatory notes are available at <http://www.constitution reformgroup.co.uk/publications/> accessed 9 September 2019 .

88 This Bill also contains provisions enabling it to be put to the electorate in a postlegislative referendum.

89 Kezia Dugdale, former Leader of the Scottish Labour Party,called for a federal solution in December 2016 ('Kezia Dugdale calls for 'new Act of Union', BBC Neres (7 December 20I6) <https://www.bbc.com/news/uk-scotland-scotland-politics38223719> accessed 17 September 2019). See also the 2006 Steel Commission, spearheaded by the Scottish Liberal Democrats, which advocated 'fiscal federalism' ('Steel Commission calls for major powers to go to Holyrood', The Scotsman (5 Macrh 2006) <https://www.scotsman.com/news/politics/steelcommission-calls-for-major-powers-to-go-to-holyrood-I-I409905> accessed 17 September 20I9. 
the current JMC, which he dismissed as a 'talking shop'.90 A federal constitution would allow Scotland, Wales, and Northern Ireland to considerably increase their powers. For instance, they could acquire the authority to issue work permits granting the right to work in devolved territories, but not elsewhere in the UK. Such a solution would mandate considerable new intergovernmental arrangements for the UK, possibly transforming the House of Lords into a territorial second Chamber, such as exist in federal states.

Admittedly, there would be problems with such a solution, not least the seemingly intractable problem of how to include England, which accounts for about 85 per cent of the UK population, and has no devolved government to date. There is also the challenge of gaining support for a written, federal constitution, which would probably need to be agreed by some form of Constitutional Convention, in other words a gathering of individuals to agree a formal text. At present both devolved and the UK governments seem uninterested, given that the UK government appears to ignore the devolved governments and, in Scotland, calls for independence are more often heard than for federalism. First Minister Nicola Sturgeon has claimed that a second independence referendum must be held by May 202I if Brexit goes ahead, and a Referendums (Scotland) bill, has already been introduced. There are plans for a 'citizens assembly' in Scotland to discuss Brexit and independence. ${ }^{91}$ Support for Irish reunification has grown since the 2016 Brexit referendum. Many Northern Ireland economists and business leaders worry that a 'No deal' Brexit would lead to a hard border with Ireland, which could cripple the economy, and threaten the peace under the B/GFA. Polls have shown support for a reunification approaching 50 per cent in Northern Ireland and Ireland, especially if Britain leaves without an agreement. ${ }^{92}$

90 'Brexit an opportunity to reinvent the UK - Carwyn Jones' BBC Neres (I7 June 20I7) $<$ https://www.bbc.co.uk/news/uk-wales-politics-40274840/> accessed 9 September 20I9.

91 $\quad$ See 'Indyref2 'framework' bill published at Holyrood' BBC News (29 May 2019) $<$ https://www.bbc.com/news/uk-scotland-scotland-politics-48435198> accessed Io September 2019.

$92 \quad$ See e.g. Nick Eardley, 'Brexit: "Very real" chance of Irish unity poll if no deal' $B B C$ Neres (8 February 2019) <https://www.bbc.co.uk/news/uk-politics-471707II> accessed I3 September 2019 . 
Such attitudes, and distinct political identities, register against a comprehensive attempt to manage issues of disputed authority and the challenges of Brexit. On the other hand, federalism is a flexible concept, giving rise to many constitutional and institutional possibilities. And, in Madison's words, it provides for 'Ambition to counteract Ambition'93 - a situation that seems to be lacking in the UK at present, where the executive supremacy of the UK government controls most constitutional affairs.

Brexit is not the first occasion on which Britain has encountered challenges to its very constitutional identity. Past 'acts of union and disunion' such as the loss of former US colonies and the British Empire, the admission of Scotland and Ireland into the UK Union, their departure or possible departure, and UK's membership in the EU since 1973, all provide precedents which help understand how a British constitutional identity has been shaped or dismantled. They show how it has determined and dealt with issues of union, sovereignty and devolution of power, and how such multiple and various relationships might play their part in the future of an EU without Britain as a member. The UK might have weathered these past incidents, but is it capable of managing Brexit?

\section{CONCLUSION}

Brexit could precipitate the disintegration of the UK. The UK is not federal, but is profoundly diverse with some federal qualities, comprising four nations each possessing distinct historical, political, cultural and linguistic traditions. If the UK is to function effectively as a single state, then constitutional structures must acknowledge this variety. Yet, at present, the UK lacks a constitutional form acceptable to all parts of the Union. Instead, Brexit has been allowed to compress parliamentary sovereignty into an executive sovereignty that, by imposing a uniform approach, threatens the UK Union. Britain has a tradition of autonomous executive power deriving from a Hobbesian concept of absolute sovereignty. As Marquand argues, this is a 'highly eccentric' understanding: 'Sovereignty, in this understanding, is a kind of billiard ball - impermeable, indivisible and unshareable [...] You are either in government or in opposition. You are either the majority or the

93 James Madison, 'Federalist Papers, No 51' in Clinton Rossiter (ed) The Federalist Papers (Mentor 1961) 320. 
minority.' ${ }^{194}$ What Marquand terms a 'billiard ball' concept of sovereignty makes federalism impossible, because it sees sovereignty as indivisible, and thus impossible to share between different levels of British government.

Yet this sovereignty is a confused one ${ }^{95}$ and also essentially English. Indeed, in his famous work, Dicey referred to the 'English' rather than 'British' Constitution. ${ }^{96}$ And this notion of parliamentary sovereignty has been a visceral barrier to Britain's relationships with the EU. Why else the demand for 'Take Back Control'97 in the referendum, and also the reference in the Government White Paper on the 'Great Repeal Bill' which stated that, '[a]t the heart of that historic decision was sovereignty. A strong, independent country needs control of its own laws. That, more than anything else, was what drove the referendum result: a desire to take back control.' ${ }^{98}$ But now this affective, irrational belief in a central parliamentary sovereignty presents a barrier to a divided sovereignty in the UK and the possibility of a federal Britain.

Brexit has revealed many flaws in Britain's aged Constitution. Too many of its uncodified rules and conventions are unclear or ambiguous, including many of serious national importance. There is so much that is uncertain: what is the status of an 'advisory' referendum? What exactly are the powers of the executive? How can Scotland be one of the most devolved territories in the world, and yet play so small a part in Brexit negotiations and find that its 62 per cent vote in favour of Remain is seemingly irrelevant? What input can devolved governments have in Brexit policy? Can devolved governments continue to apply the EU Charter after Brexit? Surely the answers to such

94 D Marquand, 'Federalism and the British: Anatomy of a Neurosis' (2006) 77 The Political Quarterly 150.

95 On this, see S Douglas-Scott, 'Brexit and the Siren-like allure of sovereignty' in E Fahey and T Ahmed (eds) On Brexit: Law, Fustices and injustices (Elgar 2019)

96 Dicey (n 3).

97 This expression was used constantly by the Leave campaign in the run up to the 2016 referendum - for an elucidation of its significance, see eg T Haughton, 'It's the slogan, stupid: The Brexit Referendum', available at $<$ https://www.birmingham.ac.uk/research/perspective/eu-ref-haughton.aspx> accessed I7 September 2019.

98 Legislating for the United Kingdom's withdrawal from the European Union, Cm 9446 (March 2017) 7. 
questions should be easier to ascertain. What is the point of asserting a strong, unitary British Constitution, if that Constitution fails to deliver anything like stability when needed, as it has with Brexit?

But even if it is desirable to codify the constitution, how to bring that about? By some sort of Constitutional Convention? Or possibly a 'People's Assembly'? But it is possible that the Brexit crisis, far from constituting a 'constitutional moment', has deepened existing divisions in society. A lack of concern to resolve things in common, along with very distinct political identities, militate against the calm, mature reflection necessary to address issues of contested authority in a holistic manner. The present turbulent circumstances foster passion, not reason.

Brexit may have both centripetal or centrifugal effects ${ }^{99}$ for the internal structure of the UK. It is possible these may be centripetal: there may be pressures towards recentralization as Westminster reasserts its sovereignty and the European legal framework is replaced by the British one. Brexit will return powers from the EU, but they will concentrate in Westminster, which could establish itself as the state core. Scottish, Irish and Welsh unionists might choose the UK union over the European union, regardless of whether they were Leave or Remain supporters.

On the other hand, there exist centrifugal forces. A potential exists for state disintegration if Scotland secedes or Ireland reunifies. A united Ireland would be a Member State of the EU; an independent Scotland would have a good prospect of joining. Such a scenario would keep both territories within the EU, but involve new borders with the remaining United Kingdom.

I conclude with an excerpt from Mohsin Hamid's Exit West, which seems to capture very well the current situation:

Reading the news at that time one was tempted to conclude that the nation was like a person with multiple personalities, some insisting on union and some on disintegration, and that this person with multiple personalities was furthermore a person whose skin appeared to be dissolving as they swam in a soup full of other people whose skins likewise seemed to be dissolving. Even

99 See on 'centripetal' and 'centrifugal', J Bryce, 'The Action of Centripetal and Centrifugal Forces on Political Constitutions' in J Bryce, Studies in History and Furisprudence, vol I (Oxford Clarendon Press I90I). 
Britain was not immune from this phenomenon, in fact some said Britain had already split, like a man whose head had been chopped off and yet still stood, and others said Britain was an island, and islands endure, even if people who come to them change, and so it had been for millennia and so it would be for millennia more. ${ }^{\text {Ioo }}$

Will the future of the UK be characterized by union or disintegration? The thistle, rose, leek and flax flower are the symbols of the four nations of the United Kingdom, and are joined together, under the Greek letter Omega - symbolising finality - in the official emblem of the UK Supreme Court, in Parliament Square in London. Yet, will this Court emblem (or for that matter, the 'Union Jack' flag of the UK) survive Brexit? The eventual outcome of Brexit may be that, in leaving one union - the EU Britain may in fact destroy its own union - the UK.

roo Mohsin Hamid, Exit West (Riverhead Books 2017) 158. 